GLOBAL JOURNAL OF AGRICULTURAL SCIENCES VOL. 18, 2019: 19-29

COPYRIGHT@ BACHUDO SCIENCE CO. LTD PRINTED IN NIGERIA ISSN 1596-2903 www.globaliournalseries.com, Email: info@globaljournalseries.com

\title{
PROXIMATE, MINERAL AND ANTI-NUTRITIONAL COMPOSITIONS OF RAW AND PROCESSED AFRICAN YAMBEAN (SPHENOSTYLIS STENOCARPA) SEEDS IN CROSS RIVER STATE, NIGERIA
}

\author{
ANYA, M. I. AND OZUNG, P.O. \\ (Received 9 January 2019; Revision Accepted 11 February 2019)
}

\begin{abstract}
African yambean (Sphenostylis stenocarpa, Hochst. Ex A. Rich, Harms) is an indigenous legume in tropical Africa. This food crop legume is highly under-exploited and very little scientific information is available in literature. In this study, the chemical composition (proximate, minerals and anti-nutritional profile) of raw and processed African yambean (AYB) seeds was investigated. Seeds of brown seed coat landraces of African yambean were collected from various locations in the Northern part of Cross River State. The seed characteristics were noted and subjected to boiling and toasting for one hour and thereafter evaluated for proximate composition, gross energy, mineral and antinutritional properties. Results showed that boiling significantly $(P<0.05)$ increased crude Protein $(C P)(22.10 \%)$, ether extract (EE) $(7.53 \%)$ and gross energy (GE) $(5.23 \mathrm{Kcal} / \mathrm{g})$ compared to the raw $(21.61 \% \mathrm{CP}, 5.12 \%$ EE and 4.88 $\mathrm{Kcal} / \mathrm{g} \mathrm{GE})$ as well as toasted seeds $(21.41 \% \mathrm{CP}, 5.195 \mathrm{EE}$ and $4.51 \mathrm{Kcal} / \mathrm{g} \mathrm{GE})$. Toasting significantly $(P<0.05)$ increased nitrogen free extract (NFE) $(50.65 \%)$ and ash values. Processing (boiling/toasting) had significant $(P<0.05)$ effect on mineral composition ( $\mathrm{Ca}, \mathrm{Mg}, \mathrm{K}, \mathrm{Na}$ and $\mathrm{Fe}$ ) of the seeds except for phosphorus. Boiling significantly $(P<0.05)$ reduced phytate $(0.68 \%)$, alkaloid $(0.70 \%)$ and trypsin-inhibitor $(0.08 \mathrm{IU} / \mathrm{mg})$ contents. Results have shown that African yambean seeds are rich sources of nutrients but have low human preference for food. But have a high potential as an energy/protein source in livestock feeds. The boiled AYB seeds had highest CP, mineral and lowest in anti-nutrient contents. Hence, boiling was the preferred processing method for AYB seeds.
\end{abstract}

KEYWORDS: Boiling, legume, nutrient profile, toasting, yambean

\section{INTRODUCTION}

The African yambean (Sphenostylis stenocarpa Hochst. Ex A. Rich.) Harms, originated in Africa. Wild forms of this species have been observed in all countries along the Gulf of Guinea, from Senegal to the South of Nigeria. They are also found in the eastern and northern regions of Ethiopia, Eritrea, Mozambique and Tanzania (Baudoin and Mergeai, 2001). The species, Sphenostylis stenocarpa belongs to the genus Sphenostylis, sub tribe; Phaseolinae, tribe; Phaseoleae, family; Leguminosae, and sub family; Papilionoideae (Faboideae) - the pea family. The yambean is a perennial herbaceous plant, treated mostly as an annual crop and used for both its seeds and tubers. The stems may be prostrate or climbing and range from 1 to 3 meters in length. Cultivated in Nigeria mainly for its seeds, it is also grown for tubers in Cote d' Ivoire, Ghana, Togo, Cameroon, Gabon, Democratic Republic of Congo, Ethiopia, and parts of East Africa, notably Malawi and Zimbabwe (NRC, 2006). One theory holds it that the plant's English name comes from this combination, more likely because the plant has 'yams' on bottom and 'beans' on top. The pods are straight, very elongated, and slightly woody and range from $10-$ $30 \mathrm{~cm}$ in length. The fruit contains $20-30$ seeds which are laterally compressed and sub-cylindrical or ovoid in shape. The seed coat is usually orange-brown, sometimes with dark spots (Baudoin and Mergeai, 2001). The seeds themselves are large (up to $1 \mathrm{~cm}$ long) and can vary from white to brown and black. Some are speckled or marbled in brown and white, and the veined seeds are known as well (Sorenson, 1996; NRC, 2006).

The African yambean (AYB) is a typical African plant being grown in most parts of the hot and humid tropical African regions at middle and low altitudes and more specifically in Southern Nigeria (Baudoin and Mergeai, 2001). It is found from sea level up to an altitude of $1,800 \mathrm{~m}$ and thrives in places with an annual rainfall of $800-2000 \mathrm{~mm}$. It performs well on almost all soils provided they are slightly acidic $(\mathrm{pH} 5.0-6.5)$, thus the plant thrives in weathered soils where rainfall can be extremely high. It tolerates even the highly acidic,

Anya, M. I., Department of Animal Science, University of Calabar, Calabar, Nigeria.

Ozung, P.O., Department of Animal Science, University of Calabar, Calabar, Nigeria. 
infertile and highly leached sites that are the humid tropical lowland's special course (NRC, 2006). Part of the reason for this great adaptability to bad substrates is that like other members of the legume family, the African yambean enjoys a symbiosis with bacteria that fix nitrogen from the air. This special agronomic attribute of the African yambean makes it very valuable in subsistence agriculture because the crop is hardy, resistant to pest, diseases and drought and can be managed with minimal care being very prolific in seed production.

Yambean is propagated from seeds and tubers. The duration of the crop cycle is 150 to 300 days. In Southern Nigeria, it is usually interplanted with yams, okra and other twining beans and trained up the same stakes. The best yields are obtained when grown in association with yam, maize and okra (Boudoin and Mergeai, 2001). Average yields of $300-500 \mathrm{~kg}$ of dried seeds per hectare have been reported (Boudoin and Mergeai, 2001). However, studies in Nigeria have demonstrated yields of 2 tonnes per hectare, an exceptional amount for an underdeveloped legume (NRC, 2006). Studies at the International Institute of Tropical Agriculture (IITA) in Ibadan reveal that Nigeria has the most productive line of African yambean and yields of 1860 - $2000 \mathrm{~kg}$ of seeds per hectare have been reported in Nsukka, Nigeria (Okpara and Omaliko, 2001; NRC, 2006).

So little is known about African yambean (AYB) (Moyib et al., 2008). Okigbo (1973) first introduced African yambean at a grain legume improvement workshop held at IITA, Ibadan. AYB is classified as a minor grain legume because it is under-exploited (NRC, 1979; Saka et al., 2004). The crop is cultivated for both tuber and seeds in tropical Africa (Moyib et al., 2008). It produces small tubers that look like elongated sweet potatoes but taste more like Irish potatoes. AYB is known in Nigeria as "girigiri" being very popular in Eastern Nigeria (Moyib et al., 2008) with numerous common names like lbo (Okopo dudu), Obudu (Bitei), Obanliku (Azaba), Yoruba (Sheshe), etc. Preliminary survey reveals that the consumption of $A Y B$ is not very popular and is less preferred compared to other legumes. Consumption however, has been limited to famine and other periods of great need as a coping strategy for household food security (Klu et al., 2001; Maziya - Dixon, 2004). AYB is being neglected in most Nigerian homes for consumption partly because of long hours of cooking ( 8 - 10 hours), after soaking in water and tedious manual removal of the seed coat (Thomas et al., 2005). The lengthy cooking time, much longer and up to 12 hours is probable reason for this neglect and possible extinction of this crop considering the cost of fuel for cooking (Wokoma and Aziagba, 2001; Azeke et al., 2005). With all its potentials, African yambean remains a neglected and underutilized crop with no concerted efforts to advance it. Because of this neglect, farmers who know the crop best are switching to crops for which more help is available, and sadly their heritage of seeds and age-old wisdom with the crop are slowly fading away (NRC, 2006). However, cultivation of this crop for use as livestock feeds could generate interest to farmers and prevent the crop from becoming extinct. This study therefore evaluated the proximate, mineral and anti-nutritional compositions of raw and processed
African yambean seeds found in Cross River State, Nigeria.

\section{MATERIALS AND METHODS}

\section{Procurement of African yambean seeds}

Seeds of African yambean (Sphenostylis stenocarpa) were procured from local farmers in Obudu and Obanliku Local Government Areas in the Northern part of Cross River State, Nigeria. The seeds were undecorticated and comprised mainly the brown seed coat variety (Landraces).

\section{Processing of seeds for analyses}

African yambean seeds were air-dried for 48 hours and stored in air-tight plastic containers under cool and dry conditions prior to use. Samples for analyses included the raw seeds, seeds boiled for one hour and seeds toasted for one hour.

\section{Raw seeds}

One kilogram of the raw seeds was thoroughly cleaned of any extraneous material and divided into two equal parts $(0.5 \mathrm{~kg})$, before being milled using $2 \mathrm{~mm}$ sieve size and subsequently used for chemical analyses.

\section{Boiled seeds}

Two litres of water each were put into two separate pots and the water made to boil at $100^{\circ} \mathrm{C}$. Two lots $(0.5 \mathrm{~kg}$ each) of the raw seeds were put into the two separate pots made to boil for one hour. At the end of boiling, the water was decanted and boiled seeds dried in the sun to a constant moisture content of $10 \%$ before milling using a $2 \mathrm{~mm}$ sieve size and subsequently used for chemical analyses.

\section{Toasted seeds}

Another two lots of raw seeds weighing $0.5 \mathrm{~kg}$ each were subjected to toasting in an oven at a temperature of $100^{\circ} \mathrm{C}$ for one hour. Thereafter, the toasted seeds were cooled and milled using a $2 \mathrm{~mm}$ sieve size and subsequently used for chemical analyses.

\section{Preparation of seed samples for analyses}

From each of the raw, boiled and toasted seeds, triplicate samples were collected for proximate, mineral assay, gross energy and anti-nutritional content determinations.

\section{Proximate composition}

The AOAC (2000) procedure was employed to determine the proximate composition of the raw, boiled and toasted seed samples: The analyses were carried out at the International Institute for Tropical Agriculture (IITA), Ibadan, Nigeria.

\section{Mineral assay}

The mineral elements selected for determination were calcium, magnesium, sodium, potassium, phosphorus, copper, iron, zinc, manganese, cobalt and chromium. Calcium, magnesium, copper, iron, zinc, manganese, cobalt and chromium were determined using Techcomp AA6000 Atomic Absorption Spectrophotometer. Sodium and potassium were also determined using AtomicAbsorption Spectrometer and further confirmed using a 
digital flame photometer, while phosphorus was determined through Colorimetry. The colour was developed using ammonium molybdate reagent and read on spectronic 20. All determinations followed AOAC (2000) procedure and were carried out at IITA, Ibadan - Nigeria.

\section{Gross energy}

The AOAC (2000) method, involving combusting pelleted samples in adiabatic oxygen bomb calorimeter was used to determine the gross energy. The following equation was applied to get the gross energy of the samples.

Gross energy $=\mathrm{W} \times \mathrm{T}-2.3 \mathrm{~L}-\mathrm{V} / \mathrm{g}$

Where:

$\mathrm{W}=$ Energy equivalent of calorimeter or water equivalent of calorimeter.

$\mathrm{T}=$ Temperature rise

$2.3=$ a constant (heat of combustion of wire $=$

$2.3 \mathrm{cal} / \mathrm{cm}$ or $1400 \mathrm{cal} / \mathrm{g}$

$\mathrm{L} \quad=\quad$ Length of wire burnt

$\mathrm{G}=$ Weight of sample in gram

The Gross energy determination was also carried out at IITA, Ibadan - Nigeria.

\section{Determination of anti-nutritional/toxic compounds}

The following anti-nutritional/toxic compounds were determined in the samples: Phytate, tannin, saponin, hydrogen cyanide, oxalate, phenol, alkaloid, steroid and trypsin inhibitors. Consequently, alkaloid was extracted using a slight modified method of Maxwell et al. (1995). Each dried sample was homogenized and the alkaloid extracted from 10 grams of the sample for 4 hours using $20 \% \mathrm{v} / \mathrm{w}$ acetic acid in ethanol. The extract was filtered to remove cellulose debris and then concentrated to about one quarter of the original volume. Exactly $1 \% \mathrm{NH}_{4} \mathrm{OH}$ was added drop wise until a precipitate occurred. The crude alkaloid was dried to constant weight in an oven and the percentage alkaloid calculated.

The Bohm and Kocipai - Abyazan (1994) method was used for the determination of tannin and flavonoid while saponin was determined using the method of Peng and Kabayashi (1995). Cyanogenic glycoside was estimated by determining the hydrogen cyanide $(\mathrm{HCN})$ released on hydrolysis of the seed meal samples. Phytic acid was determined using the procedure laid down by Wheeler and Ferrel (1971) while trypsin inhibitor was determined using the method of Kunitz (1945). All other determinations were carried out using standard analytical procedures (AOAC, 2000).

Statistical analysis
All data obtained from the characterization experiment was subjected to analysis of variance (ANOVA) as applicable to a completely randomized designed (CRD) using the SPSS 15.0 (2006) statistical package with a statistical model as

$Y i j=\mu+T i+e i j$

Where $Y \mathrm{ij}=\mathrm{i}^{\text {th }}$ observation on the $\mathrm{j}^{\text {th }}$ treatment

$\mu=$ overall mean

$\mathrm{Ti}=$ effect of treatment

eij $=$ random error.

Significant mean differences between treatments were separated using Duncan Multiple Range Test (Duncan, 1955) as outlined by Obi (1991).

\section{RESULTS AND DISCUSSION}

\section{Proximate composition}

The intact raw seeds had a mean crude protein value of $21.61 \%$ (Table 1). This agrees with the reported crude protein ranges of $20-34 \%$ (Ezueh, 1984; Santos et al., 1996; Grunberg et al., 1999; Azeke et al., 2005; NRC, 2006) and $21-29 \%$ (Oshodi et al., 1997; Moyib et al., 2008) respectively. The observed differences in these ranges of crude protein values could be governed and attributed to varied and environmental differences (NRC, 2006). The crude protein values of the boiled and toasted seeds also fell within the range reported by numerous workers. This crude protein level ranks with those of other lesser known legumes, Jack bean seed (25.88\%), mucuna seed $(30.60 \%)$, pigeon pea $(25.04 \%)$, sword bean (25.83), lima bean (21.50\%), Canavalia plagiosperma $(24.21 \%)$ but lower than groundnut $(34.88 \%)$ and that of soybean $(39 \%$ - 43.06$)$, the richest among the vegetable protein sources (Ukachukwu and Obioha, 2000; Akinmutimi, 2004a; Ahamefule, 2005; Odoemelam and Ahamefule, 2006; Ukpabi, 2007). The amino acid profile of African yambean seeds compares favourably with most of the plant protein sources. Its high level of methionine $(1.2 \%)$ and lysine $(8.3 \%)$, equal to or better than those of soybean and corresponding to WHO/FAO recommendations (Ezueh, 1984; Sales et al., 1990; Evans et al., 1997; Ekop, 2006). This high level of essential amino acids could suggest it as a high quality feedstuff for both human and animals.

The ether extract of the raw, boiled and toasted African yambean seed was $5.12,7.53$ and $5.19 \%$ respectively. The oil content is however high and above the range of ether extract values for conventional protein sources such as soybean (1.5\%) and groundnut (3.2\%) (Olomu, 1995). The oil content of this seed was higher compared to other alternative 


\begin{tabular}{lllll}
\multicolumn{5}{c}{ Table 1: Proximate composition (\%) of Raw, Boiled and Toasted African yambean seeds } \\
\hline Proximate composition (\% of DM) & Raw & Boiled & Toasted & SEM \\
\hline Dry matter & 87.55 & 88.50 & 89.10 & 0.19 \\
Crude protein & $21.61^{\mathrm{ab}}$ & $22.10^{\mathrm{a}}$ & $21.41^{\mathrm{b}}$ & 0.21 \\
Ether extract & $5.12^{\mathrm{b}}$ & $7.53^{\mathrm{a}}$ & $5.19^{\mathrm{b}}$ & 0.80 \\
Crude fibre & $7.00^{\mathrm{a}}$ & $5.92^{\mathrm{ab}}$ & $5.50^{\mathrm{b}}$ & 0.45 \\
Ash & 5.35 & 5.28 & 6.35 & 0.38 \\
NFE & $48.47^{\mathrm{b}}$ & $47.65^{\mathrm{b}}$ & $50.65^{\mathrm{a}}$ & 0.90 \\
GE (Kcal/g) & $4.88^{\mathrm{a}}$ & $5.23^{\mathrm{a}}$ & $4.51^{\mathrm{a}}$ & 0.21 \\
\hline
\end{tabular}

${ }^{a b}$ Means on the same row with different superscripts differ significantly $(P<0.05)$.

protein sources such as pigeon pea $(2.33 \%)$, velvet bean (1.61\%), Mucuna cochinchinensis (4.52\%), sword bean (2.94\%) (Ukachukwu, 2000; Akinmutimi, 2004b; Ahamefule, 2005; Akinmutimi, 2007) but fell within the range reported for Canavalia plagiosperma seeds (5.94\%) (Odoemelam and Ahamefule, 2006). However, reports show that African yambean seeds are high in lipids/oil, about 20 - 23\% (Gruneberg et al., 1999), $8.25 \%$ (Oshodi et al., 1997). Studies by several authors (Jimenez, 1994; Santos et al., 1996) agree that the oil of African yambean has a composition comparable to that of groundnut and cottonseed oil, being high in palmitic and oleic acids. However, the high oil content of the seeds can cause rancidity in feeds. This could be overcome through extraction of the oil before being used in formulating feeds or by the addition of antioxidants.

The crude fibre (CF) content of the raw, boiled and toasted African yambean seeds was also observed to be high $(7.00,5.92$ and $5.50 \%)$ respectively. The level of crude fibre in the seeds does not make it undesirable especially for ruminant animals. Though, the CF value of the raw seeds was high, the boiled and toasted seeds had values that fell within the CF values when compared with conventional grain legumes such as groundnut cake and soybean meal with 5.0 and $6.5 \%$ CF, respectively (PNMP, 1995; Akinmutimi, 2007). However, the CF value of the raw seeds fell within the range reported for most alternate legume seeds, Pigeon pea $(7.50 \%)$ (Ahamefule, 2005), Canavalia species $(6.49-12.87 \%$ ) (Udedibie and Nkwocha, 1990; Odoemelam and Ahamefule, 2006). Fibre is important in the diet of farm animals; it acts as diluents. Its absence in diets leads to incidence of a wide range of diseases which include colon biventricular, diabetes mellitus, obesity and coronary artery diseases (Oke et al., 2007). Some level of fibre is also necessary for proper bowel movement (Odoemelam and Ahamefule, 2006).

African yambean seeds from the analysis is high in ash. All treatments, raw (5.35\%), boiled $(5.28 \%)$ and toasted $(6.35 \%)$ had values that compared favourably with other alternative vegetable protein sources like pigeon pea, lima bean, lablab bean, mucuna bean, Tephrosia brateolata seed and castor oil seed with ash levels of 2.85, 3.22, 3.56, 4.31, 5.62 and 5.61 percent respectively (Ahamefule, 2005; Akinmutimi, 2007; Carew et al., 2008; Nsa, 2008). Though, the values obtained in this study compared favourably, they were however lower than the ash content of $9.06 \%$ reported for Canavalia plagiosperma (Odoemelam and Ahamefule, 2006) and higher than $3.26 \%$ total ash reported by Oshodi et al. (1997) for yambean seed. The high ash value in African yambean seed is an indication of its high mineral content.
The NFE values of raw, boiled and toasted African yambean seeds were $48.47,47.65$ and $50.65 \%$ respectively. Though, these values are slightly low, they however fell within the range of $50-57 \%$ and $59.72 \%$ as reported by Ezueh (1984) and Oshodi et al. (1997) respectively for this same seed. Varied seed landraces and environmental factors including different processing/analytical methods could be responsible for these differences. The NFE values obtained in this study were higher when compared to that of conventional protein sources such as groundnut cake $(23.84 \%)$ and soybean and $(28.6 \%)$ as reported by Olomu (1995). The NFE values were very comparable with those of some alternative protein sources such as velvet bean $(55.5 \%)$ (Akinmutimi, 2007). Canavalia spp. (51.28\%) (Odoemelam and Ahamefule, 2006). This however is an indication that the seed could serve as a high source of carbohydrate which implies higher total digestible nutrient (TDN).

The gross energy value of raw, boiled and toasted African yambean seeds were 4.48, 5.23 and $4.51 \mathrm{kcal} / \mathrm{g}$, respectively. These values were similar to that of some conventional legumes such as soybean $(5.52 \mathrm{kcal} / \mathrm{g})$ and groundnut seeds $(4.55 \mathrm{kcal} / \mathrm{g})$ reported by Maynard and Loosli (1979). The values obtained in this study also compares favourably with that of most alternative protein sources such as linseed cake (5.12 $\mathrm{kcal} / \mathrm{g})$, castor oil seed $(5.03 \mathrm{kcal} / \mathrm{g})$, Canavalia spp. $(4.48 \mathrm{kcal} / \mathrm{kg})$, lima bean $(4.12 \mathrm{kcal} / \mathrm{g})$, velvet bean (4.409 kcal/g) (Odoemelam and Ahamefule, 2006, Akinmutimi, 2004b; 2007; Nsa, 2008). This suggests the potential of African yambean seeds as good energy supplements.

Table 1 shows result on the proximate composition of the raw, boiled and toasted African yambean seeds. There were significant $(P<0.05)$ differences between the raw and processed seeds for some of the parameters considered except for dry matter, ether extract or ash content. This is in agreement with the pattern of results obtained by Akinmutimi (2007) and Ahamefule and Odoemelam (2008) for Mucuna pruriens and Canavalia plagiosperma seeds respectively.

For crude protein, the processing methods or thermal treatments (boiling and toasting) were significant $(P<0.05)$. Subjecting African yambean seeds to boiling brought about significant $(P<0.05)$ increase $(22.10 \%)$ in crude protein over the toasted $(21.41 \%)$. This result was in agreement with the pattern obtained by Ukachukwu (2000); Akinmutimi (2004b) and Ahamefule and Odoemelam (2008) for Mucuna cochichinensis, Canavalia gladiata and Canavalia plagiosperma respectively. Boiling for 60 minutes caused significant 
increase $(\mathrm{P}<0.05)$ in crude protein $(22.10 \% \mathrm{CP})$, followed by raw seeds $(21.61 \% \mathrm{CP})$, the least $\mathrm{CP}$ value was that from seeds toasted for 60 minutes $(21.41 \%)$. This result was similar to that obtained by Ahamefule and Odoemalam (2008) for Canavalia plagiosperma seeds and could probably be due to the burning off of some nitrogenous compounds during toasting and partly due to the loss of lysine as a donor of free amino group in a complex reaction called maillard reaction that terminates in the very brown colour observed after toasting..

The ether extract value showed that seeds boiled for 30 minutes had the highest value of $7.53 \%$ that was significantly $(\mathrm{P}<0.05)$ different from the values obtained for the raw and toasted seeds. Boiled seeds had higher ether extract content $(7.53 \%)$ compared to the toasted seeds $(5.19 \%)$. This result is in line with that of Ahamefule and Odoemelam (2008) for Canavalia plagiosperma seeds who observed the same pattern. Akinmutumi (2004b) also had similar results with the seeds of Canavalia gladiata, and Akinmutimi (2007) with Mucuna pruriens. The appreciable ether extract value of these seeds even after undergoing thermal treatment of processing could suggest that the seeds may hold promise as a potential oil seed crop.

There was a general decrease in crude fibre value among the processed seeds. These decrease was significant $(P<0.05)$, with the raw seeds having the highest value $(7.00 \%)$, while boiled seed $(5.92 \%)$ and toasted seeds $(5.50 \%)$ were similar. This result is in line with the report of Akinmutimi (2004b) for mucuna species. However, in this study, thermal processing (Boiling and Toasting) did not have any significant $(P>0.05)$ effect on the crude fibre content. This result is in line with that of Ahamefule and Odoemelam (2006) for Canavalia seeds and Ukachukwu (2000) for Mucuna cochichinensis who observed no significant $(P>0.05)$ difference in boiled and toasted seeds. The decrease in crude fibre of the boiled and toasted seeds agrees with the findings of Aletor and Ojo (1989) who reported that cooking and autoclaving generally reduced crude fibre of legumes. The observed trend in this study could be due to the softening and subsequent loss of hard coat of some of the seeds in the boiling process. However, the value of 5.92 and $5.50 \%$ for boiled and toasted seeds were still quite high for vegetable seeds when compared to the conventional legumes. The nutritional significance of fibre in livestock rations should not be overlooked. The normal peristaltic movements of the intestinal tract are dependent, in part, on internal distention which is provided by food residue (crude fibre) that is not attacked by digestive agents. Some of the crude fibre are hydrophilic and so help maintain a moist, soft condition of the faecal mass and so facilitates easy passage through the large bowel.

The ash content showed no significant $(P>0.05)$ difference between the raw and thermal treated seed samples. The toasted seeds however recorded a higher ash content $(6.35 \%)$ compared to boiling $(5.28 \%)$ and raw seeds $(5.35 \%)$ that were not significantly $(P>0.05)$ different. The above trend could be attributed to the leaching of mineral elements in water. This observation is in agreement with the reports of Udedibie and $\mathrm{Mba}$ (1994), Ukachukwu and Obioha (2000) and Nsa (2008) who attributed it to the dehulling effect of boiling treatment which may have predisposed the seeds to some kind of leaching of some of its mineral elements. Seeds boiled for 60 minutes had the least value of $(5.28 \%)$. This value was still high compared to the conventional vegetable protein sources, which is an indication that the seeds are of a very high mineral content. According to Akinmutimi (2007), this implies that its use in livestock rations can reduce the use of conventional mineral supplements thereby reducing cost of production. In this study, toasting recorded the highest value of $6.35 \%$ compared to boiling $(5.28 \%)$. This trend is in line with the report of Ukachukwu (2000), Ahamefule and Odoemelam (2006) and Akinmutimi (2007) where toasting recorded high ash values compared to boiling. However, according to Ahamefule and Odoemelam (2006), the higher ash value for toasted seeds may be as a result of loss of moisture due to the application of dry heat, which concentrates the inorganic content which explains the results obtained in this study.

The nitrogen-free extract (NFE) varied from $48.47 \%$ in the raw seeds to $47.65 \%$ (boiled) and $50.65 \%$ (toasted). Thermal processing resulted in NFE values that were significantly $(P<0.05)$ different. Toasting the African yambean seeds gave a significantly higher NFE value when compared to boiling. This result is in line with that of Ahamefule and Odoemelam (2006) for Canavalia plagiosperna seeds. The value $50.65 \%$ obtained in this study compares favourably with the report of other alternative vegetable legumes. However, the relatively low NFE value for boiled seeds could be attributed to solubilization and leaching of the starch fraction in water during boiling.

The gross energy varied from $4.88 \mathrm{kcal} / \mathrm{g}$ for raw seeds to $5.23 \mathrm{kcal} / \mathrm{g}$ for boiled and $4.51 \mathrm{kcal} / \mathrm{g}$ for toasted seeds. These values were significantly $(P<0.05)$ different. Boiling the seeds caused significantly $(P<0.05)$ higher energy value in yambean seeds $(5.23 \mathrm{kcal} / \mathrm{g})$ than raw and toasted seeds which were similar $(P>0.05)$. This result is in line with that of Ukachukwu (2000), Akinmutimi (2004a) and Ahamefule and Odoemelam (2006). This may not be unrelated with the higher ether extract value for boiled seeds as shown in Table 1. The toasted seeds having lower energy values as compared to boiled seeds may be due to volatility of energy related nutrients like ether extract by toasting. The report of Ahamefule and Odoemelam (2006) corroborates this finding in this study.

\section{Mineral composition}

The result of mineral composition of raw and processed African yambean seeds is shown in Table 2. There were significant $(P<0.05)$ differences between the raw and processed seeds. Boiling gave a significantly $(\mathrm{P}<0.05)$ higher result for calcium compared to toasting. This is in agreement with the results obtained by Akinmutimi (2004b) and Ahamefule and Odoemelam (2006) for sword bean and canavalia bean respectively. However, the value of calcium in African yambean boiled for 60 minutes $(0.53 \%)$ was higher than $0.17 \%$ reported for Canavalia plagiosperma by Ahamefule and Odoemelam (2006) and $0.02 \%$ for Mucuna pruriens by Akinmutimi (2007). Other macro minerals (Mg, K, Na and $\mathrm{Mn}$ ) followed a similar trend where boiling produced significant high $(\mathrm{P}<0.05)$ values compared to raw and 
toasted seeds except for phosphorous that was not significant in both raw and processed seeds. The magnesium values for raw, boiled and toasted seeds were $0.29,0.29$ and $0.22 \%$ respectively. These values fell in the range of magnesium values $(0.26 \%)$ reported for the legume Canavalia spp. by Ahamefule and Odoemelam (2006; 2008). The level of potassium $(0.25 \%)$ reported in the study, is lower than the potassium value $(0.30 ; 1.10 \%)$ reported by Ahamefule and Odoemelam (2008) and Akinmutimi (2007) for canavalia and velvet bean respectively, but is in line with the report of $0.23 \%$ for potassium (Akinmutimi, 2004a) for sword bean. The result obtained for sodium $(0.09 \%)$ in this study is lower compared to result reported by Ahamefule and Odoemelam (2006) for Canavalia plagiosperma $(0.17 \%)$ but higher than $0.02 \%$ reported by Akinmutimi (2007) for velvet bean. The manganese level $(0.07 \%)$ obtained in this study is lower than 0.29 $\%$ ) reported by Akinmutimi (2007) for velvet bean.

Table 2: Mineral composition of Raw, Boiled and Toasted African yambean seeds

\begin{tabular}{|c|c|c|c|c|}
\hline Mineral composition (ppm) & Raw & $\begin{array}{l}\text { Boiled } \\
(60 \mathrm{~min})\end{array}$ & $\begin{array}{l}\text { Toasted } \\
(60 \text { min })\end{array}$ & SEM \\
\hline Calcium (Ca) & $101.12^{\mathrm{ab}}$ & $112.37^{a}$ & $97.44^{\mathrm{b}}$ & 4.49 \\
\hline Magnesium (Mg) & $57.49^{\mathrm{ab}}$ & $58.26^{\mathrm{a}}$ & $44.22^{\mathrm{b}}$ & 4.56 \\
\hline Potassium (K) & $49.09^{\mathrm{ab}}$ & $49.76^{a}$ & $40.44^{\mathrm{b}}$ & 3.00 \\
\hline Sodium $(\mathrm{Na})$ & $16.74^{\mathrm{ab}}$ & $18.39^{a}$ & $12.19^{\mathrm{b}}$ & 1.54 \\
\hline Phosphorous (P) & 0.24 & 0.24 & 0.22 & 0.01 \\
\hline Manganese (Mn) & $13.07^{c}$ & $14.48^{\mathrm{a}}$ & $10.55^{b}$ & 1.15 \\
\hline Iron (Fe) & $10.56^{\mathrm{ab}}$ & $11.06^{\mathrm{a}}$ & $10.11^{\mathrm{b}}$ & 0.25 \\
\hline Copper (Cu) & $2.09^{a}$ & $1.97^{\mathrm{ab}}$ & $1.81^{b}$ & 0.06 \\
\hline Zinc $(\mathrm{Zn})$ & $6.32^{\mathrm{ab}}$ & $6.59^{a}$ & $6.13^{b}$ & 0.14 \\
\hline Silver (Ag) & 0.11 & 0.23 & 0.11 & 0.06 \\
\hline Lead $(\mathrm{Pb})$ & 1.13 & 0.15 & 0.13 & 0.49 \\
\hline Chromium (C) & 0.21 & 0.19 & 0.15 & 0.11 \\
\hline Cadmium (Cd) & 0.01 & 0.01 & 0.01 & 0.00 \\
\hline Arsenic (As) & 0.01 & 0.00 & 0.00 & 0.00 \\
\hline Aluminium (Al) & 0.02 & 0.02 & 0.02 & 0.00 \\
\hline Selenium (Se) & 0.01 & 0.01 & 0.01 & 0.00 \\
\hline Cobalt (Co) & 0.15 & 0.16 & 0.15 & 0.01 \\
\hline
\end{tabular}

${ }^{a b c}$ Means on the same row with different superscripts differ significantly $(P<0.05)$

For micro minerals, the results followed similar pattern like that of most macro minerals (except phosphorous) where boiling produced better results compared to toasting. However, results of raw, boiled and toasted micro minerals were generally not significant $(P>0.05)$. There was much disparity in mineral content between yambean seeds and those of other legumes. The high calcium and micro mineral content of this seeds is very outstanding. On the average, considering the above results, boiled seeds gave the highest value for the minerals analysed and boiling for 60 minutes proved to produce higher values for minerals. This view is corroborated by Ahamefule and Odoemelam (2006) with Canavalia plagiosperma seeds. The implication of this is the fact that if the seeds of yambean are considered as a source of mineral supplement, the seeds boiled for 60 minutes will be preferred or recommended. This fact also indicates that its usage as food or in rations for livestock will affect good metabolic processes of the body and also help to reduce the cost needed for conventional mineral sources.

\section{Anti-nutritional factors (ANFs)}

The result of the anti-nutritional factors present in African yambean seeds is presented in Table 3. Result showed that these anti-nutritional factors (Phytate, Tannin, Saponin, HCN, Alkaloid, Phenol, Oxalate, Steroids and Trypsin inhibitors) were present in both the raw and processed seeds. The presence of these antinutrients in African yambean seeds have been confirmed by several authors (Duke, 1981; Sahu and Hameed, 1983; Scramin, 1994; Gruneberg et al., 1991; Jimenez, 1994; Azeke et al., 2005; NRC, 2006). Generally, processing significantly $(P<0.05)$ reduced these anti-nutrients.

The effect of processing methods compared to the raw seeds on the phytate content was significant $(\mathrm{P}<0.05)$. The phytate or phytic acid content ranged from $0.69-0.72 \%$. This value may be quite high compared to the report of Tuleun et al. (2008a; 2008b). These workers reported phytic acid content of some varieties of mucuna bean to be from $0.08-0.22 \%$. Phytates are known to increase requirements for minerals, especially phosphorus, which forms insoluble complexes with phytic acid because of the special affinity for this metal ion and zinc (Odell and Savage, 1960; Griffiths and Thomas, 1981; Tuleun et al., 2008a; 2008b). However, this fact may be responsible for the low level of phosphorus in these seeds as shown in Table 2. Boiled African yambean seeds had significantly lower phytate content compared to the toasted and raw seeds. Thus, one may conclude that boiled seeds were better detoxified compared to other treatments. The tannin content of the raw, boiled and toasted yambean seeds ranged from 0.31 to $0.34 \%$. Boiled seeds had a lower value $(0.31 \%)$ compared to toasted $(0.34 \%)$ and raw $(0.34 \%)$. Though, these values were similar $(P>0.05)$, boiled African yambean seeds had low tannin content compared to toasted and raw seeds. Though, 
these values for tannin are lower than that reported for Canavalia plagiosperma $(0.47 \%)$ (Ahamefule and Odoemelam, 2006). This result is in line with their report where boiled Canavalia plagiosperma seeds had significantly lower tannin content compared to toasted seeds. The tannin content obtained in this study is also lower than $(0.80 \%)$ reported by Akinmutimi (2007) for Mucuna pruriens. Tannins are water soluble phenolic compounds with a high molecular weight $(>500)$ with the ability to precipitate protein particularly pepsin (Kumar, 1991). Results in this study showed that boiled African yambean seeds were better detoxified compared to raw and toasted seeds. These could be attributed to the ability of boiling method to more easily break the linkages formed by tannic acid and to overcome the intra-molecular force existing within the tannin structure (Freudenberg, 1920; Bate-smith, 1973; Ahamefule and Odoemelam, 2006), thus, improving the rate of molecular thermo-disintegration and resulting in better elimination. This suggest better digestibility of protein if boiled seeds are used for food or fed to animals, because tannic acid is known to adversely affect protein digestibility (Reed et al., 1990). However, in ruminants, condensed tannins have been shown to be beneficial (Barry, 1987; Kumar, 1991). The protein-tannin complex in the rumen dissociates post-ruminally as a sort of bypass protein and the effect of its presence may therefore be negligible (Barry, 1987; Kumar and Singh, 1984).

Table 3: Anti-nutritional factors in Raw, Boiled and Toasted African yambean seeds

\begin{tabular}{lllll}
\hline Anti-nutritional factors (\%) & Raw & Boiled & Toasted & SEM \\
\hline Phytate & $0.72^{\mathrm{a}}$ & $0.68^{\mathrm{c}}$ & $0.70^{\mathrm{ab}}$ & 0.01 \\
Tannin & 0.34 & 0.31 & 0.33 & 0.01 \\
Saponin & 0.07 & 0.07 & 0.07 & 0.00 \\
HCN & 0.03 & 0.01 & 0.02 & 0.01 \\
Alkaloid & $0.78^{\mathrm{a}}$ & $0.70^{\mathrm{b}}$ & $0.73^{\mathrm{ab}}$ & 0.02 \\
Oxalate & 0.01 & 0.01 & 0.01 & 0.00 \\
Steroids & 0.02 & 0.02 & 0.02 & 0.00 \\
Trypsin inhibitor (IU/mg) & $0.21^{\mathrm{a}}$ & $0.08^{\mathrm{b}}$ & $0.15^{\mathrm{ab}}$ & 0.04 \\
\hline
\end{tabular}

${ }^{a b}$ Means on the same row with different superscripts differ significantly $(P<0.05)$

The saponin content of raw, boiled and toasted African yambean seeds are presented in Table 3 . The saponin content of the raw, boiled and toasted seeds were however not significantly $(P>0.05)$ different. Saponins are glycosides containing a polycyclic aglycone moiety of either $\mathrm{C}_{27}$ steroid or $\mathrm{C}_{30}$ triterpeniod (Sapogenins) attached to a carbohydrate (Kumar, 1991). Saponins are characterized by a bitter taste and foaming properties. In non-ruminants, retardation of growth rate due primarily to reduction in feed intake is probably the major concern (Cheeke and Shull, 1985). In ruminants, saponins are implicated in bloat, but because saponins may also undergo bacterial degradation in the rumen, they may not retard growth of ruminant animals (Kumar, 1991). However, recent studies indicate that high quantities of saponins may inhibit microbial fermentation and synthesis in the rumen (Lu and Jorgensen, 1987). The saponin content of the processed seeds (boiled and toasted) was lower than that of the raw seeds. Thus, the boiled and toasted seeds were better detoxified of this antinutrients compared to the raw seeds. This result is in line with the report of Joshi et al. (1989) that the adverse effect of saponins can be overcome by repeated washing, boiling and autoclaving. Thus, the seeds can be rid-off saponins after prolong cooking and used as food or feedstuffs for animals.

The results obtained for the cyanide content of African yambean seeds ranged from $0.01 \%$ (boiled seed) to $0.03 \%$ (raw seeds). The value obtained in this study seems to be lower than $0.16 \%$ reported by Ahamefule and Odoemelam (2006) for Canavalia plagiosperma seed. Boiled seeds had lower cyanide content relative to toasted and raw seeds but was not significantly $(P>0.05)$ different. The cyanide $(\mathrm{HCN})$ was almost completely eliminated by boiling for 60 minutes.
This result is in line with the report of Ahamefule and Odoemelam (2006) where boiling proved very effective in the detoxification of Canavalia plagiosperma seeds of this antinutrient. This further affirms that wet heat is preferred in detoxification of yambean seeds. This almost complete detoxification after 60 minutes boiling is probably because of the very low content of cyanide in African yambean seeds. This trend is in line with the report of Liener (1966) that hydrolysis occurs rapidly when most legume bean is cooked in water and most of the liberated $\mathrm{HCN}$ is lost by volatilization. Abeke et al. (2010) reported over 60\% destruction of hydrogen cyanide $(\mathrm{HCN})$ in rongai variety of lablab seeds after cooking for only 20 minutes, which affirms the findings in this study. Ukachukwu et al. (2002) also reported that the level of cyanide found in mucuna, another alternative vegetable protein source is low. It can therefore be concluded with caution that the cyanide content of most alternative protein sources being investigated does not pose any deleterious effect if used as human food or feedstuff for animals. However, Kumar (1991) was of the opinion that ruminants are more susceptible to $\mathrm{HCN}$ (cyanide) toxicity than non-ruminants because of the hydrolytic reaction that takes place in the rumen occasioned by microbial activity.

The alkaloid content of raw, boiled and toasted African yambean seeds ranged from $0.70 \%$ (boiled seeds) to $0.78 \%$ (raw seeds). Boiling proved significant $(P<0.05)$ in reducing the level or content of this antinutrient compared to toasting. The alkaloid content of this seeds is quite high and becomes a source of worry nutritionally. The high content of this alkaloid (rotenone) is one of the major limitations in the use of this crop; hence it must always be kept in mind (NRC, 2006). In this study, though boiling for 60 minutes 
considerably reduced some of the antinutrients, it could not solve this particular problem of reducing this alkaloid substantially. According to Wokoma and Aziagba (2001) and Azeke et al. (2005), the dry (raw) bean of African yambean needs lengthy cooking to completely detoxify the seeds of this antinutrient or preferably fermentation with lactic acid as used with soybean, which greatly reduces most of these antinutrients with much less energy cost compared to cooking. The progress made by boiling in reducing the alkaloid content of yambean seeds is similar to that reported by Santos et al. (1996), where alkaloid reduction in their yambean fell from 1 to $0.6 \%$ by boiling. Because of the activities going on in the rumen, ruminants may overcome this antinutrient, but the problem becomes very important if African yambean seeds are to be used as food or for non-ruminants, fermentation with lactic acid and preferably solvent extraction of this alkaloid would be the first step in processing these seeds before use.

The oxalate content of raw, boiled and toasted African yambean seeds presented in Table 3 show that the quantity of this antinutrient is quite low in the seeds. Processing had no effect on the content of this antinutrient. Following the same trend is the content of steroids. However, report by Kumar (1991) show that oxalates are actively degraded by rumen microbes into $\mathrm{CO}_{2}$ and formic acid and that ruminant can actually adapt to high oxalate diets with minimal problems. The issue remains that oxalates may limit the calcium availability in a diet (Bamaulin et al., 1980).

The trypsin inhibitor content of raw, boiled and toasted Sphenostylis stenocarpa seeds were $0.21,0.08$ and 0.15 (IU/mg), respectively (Table 3 ). The effect of processing methods (boiling and toasting) was significant $(P<0.05)$. The trypsin inhibitor value for the boiled seeds was significantly low compared to the raw seeds, indicating they were better detoxified. This result is in line with that of Ahamefule and Odoemelam (2006; 2008) and Akinmutimi (2007) for canavalia and velvet bean respectively. It also collaborates the views of several workers, Liener and Kakade (1980); Aletor and Ojo (1989); Udedibie and Nkwocha (1990); Balogun et al. (2001) and Akinmutimi (2004b) who have reported that wet or moist heat treatment is an effective means of inactivating trypsin inhibitors. Trypsin inhibitors which are antinutrients for monogastrics do not exert any adverse effect in ruminants because they are degraded in the rumen (Cheeke and Shull, 1985). In monogastrics, hypertrophy of the pancreas represents one of the primary physiological effects of this antinutrient (Booth et al., 1960). Booth et al. (1960) were of the opinion that pancreatic hypertrophy leads to an excessive loss of endogenous protein secreted by the pancreas. Since this protein, consisting largely of pancreatic enzymes is rich in cysteine, the resulting effect is a net loss of sulphur-containing amino acids from the body.

The utility of the bean and pods of almost all legumes as animal feed is limited by the presence of Anti-nutritional factors (ANFs). These compounds also referred to as allelochemicals (Rosenthal and Janzen, 1979) may not be lethal. They diminish animal productivity, but may also cause toxicity during periods of feed scarcity or in confinement when feed rich in these substances are consumed in large quantities by animals. Also, there is the ever-present possibility that the prolonged consumption of a particular legume that may be improperly processed could bring to the surface toxic effects (Liener, 1985). However, the varied nature of most rations and suitable preparative/processing measures have been used to detoxify them. Many ANFs are heat labile (Kumar, 1991; Olaboro et al., 1991; Bressani, 1993). Hence, simple heating or autoclaving has been found useful in removing the effects of these allelochemicals. In this study with African yambean seeds, trypsin inhibitor was found to be the most heat labile followed by $\mathrm{HCN}$, saponin and phytic acid while tannin and alkaloid were found to be more heat stable. These results are in line with that of Abeke et al. (2010) with lablab seeds where more than $80 \%$ of the ANFs measured were lost after cooking for at least 30 minutes.

\section{CONCLUSION}

Considering the entire results, boiled seeds are preferred to toasted and raw because the former had relatively higher crude protein, ether extract, gross energy and mineral values. Also boiling (for 60 minutes) proved effective in detoxifying seeds of antinutrients; this will create avenue and make for effective nutrient utilization as food and as feedstuff for animals.

\section{REFERENCES}

Abeke, F. O., Sekoni, A. A., Ogundipe, S. O. and Adeyinka, I. A., 2010. Effect of cooking duration on the proximate and some anti-nutritional factors of rongai variety of Lablab purpureus. Proc., $35^{\text {th }}$ Annual Conf. Nig. Soc. for Anim. Prod., University of Ibadan, Nigeria, 14-17 March, 2010. PP. $560-562$.

Ahamefule, F. O., 2005. Evaluation of Pigeon pea cassava based diets for goat production in South - eastern Nigeria. Ph.D. Thesis. College of Animal Science and Animal production. Micheal Okpara University of Agriculture Umudike, Abia State - Nigeria.

Ahamefule, F. O. and Odoemelam, V. U., 2008. Effect of soaking duration on the proximate composition, gross energy, mineral content and some antinutritional properties of Canavalia plagiosperma seed. Proceedings of the $13^{t h}$ Annual Conference of the Animal Science Association of Nigeria (ASAN), ABU, Zaria. Sept. 15 - 19, 2008. PP. $491-494$.

Akinmutimi, A. H., 2004a. Evaluation of sword bean (Canavalia gladiata) as an alternative feed source for broiler chickens. Ph.D Thesis. Micheal Okpara University of Agriculture, Umudike, Abia State - Nigeria.

Akinmutimi, A. H., 2004b. Effects of cooking periods on the nutrient composition of Mucuna utilis seeds in Nigeria. Poultry Science Journal, 2 and 3: 45 -51 . 
Akinmutimi, A. H., 2007. Effect of cooking period on the nutrient composition of velvet beans (Mucuna pruriens). Proceedings $32^{\text {nd }}$ Annual Conference of the Nigeria society for Animal Production, University of Calabar, Calabar. March $18^{\text {th }}-$ $21^{\text {st }}$ 2007. PP. $223-236$.

Aletor, V. A. and Ojo, O. I., 1989. Changes in differently processed soyabean (Glycine max) and Phaseolus lunatus with particular reference to the chemical composition and their mineral and some inherent anti-nutritional constituents. Nahrung, 33: 10, 1009 - 1016.

Anya, M. I., 2012. Evaluation of African yambean (Sphenostylis stenocarpa) seed meal as feedstuff for goat production in the humid zone of Nigeria. Ph.D Thesis. Department of Animal Production and Livestock Management, Micheal Okpara University of Agriculture, Umudike, Abia State - Nigeria.

AOAC 2000. Association of official Analytical Chemists. Official methods of analysis $17^{\text {th }}$ edition. Washington DC. USA.

Azeke, M. A., Fretzdorff, B., Beuning, Pfaue, W., Holfzapfel, W. and Betsche, T., 2005. Nutritional value of African yambean (Sphenostylis stenocarpa): Improvement by lactic acid fermentation. Journal of the Science of Food and Agriculture 85(6): 963 - 970.

Balogun, T. F., Kaankuka, F. G. and Bawa, G. S., 2001. Effect of boiling full-fat soya seeds on its amino acid profile and on performance of pigs. Nigerian Journal of Animal Production, 28(1): 45 -51 .

Bamaulin, A., Jones, R. J. and Murray, R. M., 1980. Nutritive value of tropical browse legumes in the dry season. Proceedings of the Australian Society of Animal production, 13: 229 - 232.

Barry, T. N., 1987. Secondary compounds of forages. In: Nutrition of Herbivores. Itacker, J. B. and Termouth, J. H. (eds.), A. P. Sydney. PP. 91 120.

Bate - Smith, E. C., 1973. Haemanalysis of Tannins. The concept of relative astringency. Phytochemistry, 12: $807-912$.

Baudin, J. P. and Mergeai, G., 2001. Yambean Sphenostylis stenocarpa Hochst. ExA Rich Harms. In: Crop Production in Tropical Africa. R. H. Raemaekers (ed). $372-374$.

Bohm, B. A. and Kocipai - Abyazan, R., 1994. Flavonoid and condensed tannins from the leaves of Vaccium reticulata and Vaccium calcimium. Pacific Science Journal, 48: 458 - 463.

Booth, A. N., Robbins, D. J., Ribolin, W. E., F., Smith, A. K. and Rackis, J. J. (Eds), 1960. Prolonged pancreatic hypertrophy and reversibility in rats fed raw soyabean meal. Proc. Soc. Exptl. Biol. Med. 116: 1067.

Bressani, R., 1993. Grain quality of common beans. Food Reviews International, 9: 217 - 297.

Carew, I. B., Hardy, D., Weis, J., Alster, F., Mischler, S. A., Gernaut, A. and Zakrzewska, E. I., 2003. Heating raw velvet bean (Mucuna pruriens) reverses some anti-nutritional: effect on organ growth, blood chemistry and organ histology on growing chickens. Tropical and sub-tropical Agroecosystems, 1: $267-275$.

Duke, V. A., 1981. Handbook of Legumes of World Economic Importance. Plenum Press, New York and London.

Duncan, D. B., 1955. Multiple Range and Multiple F Tests. Biometrics, 11: 1 - 42.

Ekop, A. S., 2006. Changes in amino acid composition of African yambeans (Sphenostylis stenocarpa) and African locust beans (Parkia fillicoida) on cooking. Pakistan Journal of Nutrition, 5(3): 254 -256 .

Evans, I. M., Boulter, D., Eagleasham, A. and Dart, P., 1997. Protein content and quality of tuberous roots of some legumes determined by Chemical methods. Qualitas Planetarium/Plant food for human nutrition 27 3/4: $575-585$.

Ezueh, M. I., 1984. African yambean as a crop in Nigeria. World Crops 36(6): 199 - 200.

Freudenberg, K., 1920. Die chenie der Naturlichen Gerbstoffe. Springer - Verlag, Berlin. PP. $10-$ 16.

Griffiths, D. W. and Thomas, A. T., 1981. Phytate and total phosphorus content of field beans (Vicia faba). J. Sci. Food Agric. 34: 187 - 192.

Gruneberg, W. J., Goffman, F. D. and Velasco, L., 1999. Characterization of yambean seeds as potential sources of high palmitic acid, JAOCS 76: 1309 1312.

Hlu, G. Y. P., Amoatey, H. M., Bansa, D. and Kumaga, F. K., 2001. Cultivation and use of African yambean (Sphenostylis stenocarpa) in the Volta Region of Ghana. The Journal of Food Technology in Africa, Vol. 6: $74-77$.

Jimenez, B. A. G., 1994. Extraction de rotenone a partir de las semillas de pachydizus. M.Sc. Thesis. Escuela de Ingenieria Quimica, University of Costa Rica. Pp. 106.

Joshi, D. C., Katiyar, R. C., Khan, M. Y., Banerji, R.., Misra, G. and Nigam, S. K. 1989. Studies on Mahua Bassia latifolia seed cake saponin 
in cattle. Indian Journal of Animal Nutrition, 6: $13-17$.

Kakade, M. L. and Evans, R. J., 1980. Effect of soaking and germinating in the nutritive value of navy bean. J. Food Sci., 31: 781.

Kumar, R., 1991. Anti-nutritional factors, the potential risks of toxicity and methods to alleviate them. In: Legume trees and other fodder trees as protein sources for livestock. A. Speedy and P. Pugliese (eds). Proceedings of the FAO expert consultation held at Kuala Lumpur, Malaysia, October 1991. FAO Animal and Health paper 102, FAO, Rome.

Kunitz, M., 1945. Crystallization of a trypsin inhibitor from soyabean. Science, $101-668$.

Leiner, I. E. and Kakade, M. L., 1980. Toxic constituents of plant foodstuffs. Academic Press. New York. P. 771.

Liener, I. E., 1985. Anti-nutritional factors. In: Legumes, chemistry, Technology and Human Nutrition. R. H. Mathews (ed.) Marce Dekker Inc., New York. PP. $339-382$.

Lu, C. D. and Jorgensen, N. A., 1987. Alfalfa saponins: effect, site and extent of nutrient digestion in ruminants. Journal of Animal Nutrition 117: 919 $-927$.

Maxwell, A., Seepers, M. P. and Mootoo, D. R., 1995. Amino spirosola. N. E. Steroidal alkaloids from Solanum Spp. J. Nat. Product. 56: 821 - 825.

Maziya - Dixon 2004. Nigeria Food Consumption and Nutrition Survey. 2001 - 2003. International Institute of Tropical Agriculture IITA/National Planning Commission.

Moyib, O. K., Gbadegesin, M. A., Aina, O. O. and Odunola, A. O., 2008. Genetic variation within a collection of Nigerian accessions of African yambean (Sphenostylis stenocarpa) revealed by RAPD primers. African Journal of Biotechnology, 7(12): 1839 - 1846

NRC 1979. Tropical Legumes: Resources of the Future. Washington, D.C.

NRC 2006. Lost Crops of Africa. Volume II: Vegetables. The National Academic Press. Washington, DC.

Nsa, E. E., 2008. Chemical and Biological assay of Castor oil meal (Ricinus communis) as an alternative nutrient source in pullet birds diet. Ph.D Thesis. Micheal Okpara University of Agriculture, Umudike, Abia State - Nigeria.

Obi, I.U.,1991. Statistical methods of detecting differences between treatment means. SNAPP Press (Nig.) Ltd. Enugu, Nigeria. Pp. 45.
Odell, B. L. and Sauage, J. E., 1960. Effect of phytic acid on zinc availability. Proc. Soc. Exptl. Biol. Med. 103: 304.

Odoemelam, V. U. and Ahamefule, F. O., 2006. Effect of de-hulling on proximate composition, antinutritional properties and mineral content of Canavalia plagiosperma seed. Trop. J. Anim. Sci. 9(2): $35-43$

Oke, D. B., Fetuga, B. L. and Tewe, O. O., 1996. Effect of autoclaving on the anti-nutritional factors of cowpea varieties. Nigerian Journal of Animal Production, 23: 33 - 38.

Okigbo, B. N., 1973. Introducing the yambean Sphenostylis stenocarpa Hochst ex A. Rich. Harms. In: Proceedings of the first IITA Grain legume Improvement Workshop $29^{\text {th }}$ Oct. $-2^{\text {nd }}$ Nov. Pp. $224-238$.

Okpara, D. A. and Omaliko, C. P. E., 2004. Response of African yambean (Sphenostylis stenocarpa) to sowing date and plant density. Indian J. of Agric. Sci. 67(5): $220-221$

Olaboro, G., Okot, M. W., Mugerwa, J. S. and Latshawa, J. D., 1991. Growth - depressing factors in velvet beans fed to broiler chicks. East African Agric. and Forestry Journal, 57(2): 103 - 110.

Oshodi, A. A., Ipinmoroti, K. O. and Adeyeye, E. I., 1997. Functional properties of some varieties of African yambeans (Sphenostylis stenocarpa) flour. Int'l. J. Food Sci. Nutr. 48(4): 243 250.

Peng, J. P. and Kabayashi, H., 1995. Novel furastonol glycosides from allium. (Anacrostenon), Plant Media 6: 58 - 61 .

PNMP 1995. Pfizer Nutrient Master plan, Ikeja. Lagos Nigeria.

Reed, J. D., Soller, H. and Woodward, A., 1990. Fodder tree and straw diets for sheep: Intake, growth, digestibility and the effect of phenolics on nutrient utilization. Animal Feed Science and Technology, 30: 39 - 50 .

Rosenthal, G. A. and Janzen, D. H., 1979. Herbivores: Their Interaction with Secondary Plant Metabolites. Academic Press. New York.

Sahu, R. C. and Hameed, S. F., 1983. Assessment of the rotenoids of Indian yambean seeds. IAAS Journal, 41 -2: 57 - 63.

Saka, J. O., Ajibade, S. R., Adeniyan, O. N., Olowoyo, R. B. and Ogunbodede, B. A., 2004. Survey of under-utilized grain production systems in the Southwest Agricultural Zone of Nigeria. Agric. Food J. 6: 93 - 108 
Sales, A. M., Baldini, V. L. S., Cunha, M. F. and Henrigues, E. A., 1990. Perfil electroboretico e composicao de amino acidos de sementes de jacatupe. Gien Ga Technologia de Alimentos, 10(1): $87-108$.

Santos, A. C. O., Cavalcanti, M. S. M. and Coello, L. C. B. B., 1996. Chemical composition and nutritional potential of yambean seeds. Plant Food for Human Nutrition, 49: 36 - 41.

Scramin, S., 1994. Estudio fitoguimico do genero Pachyrhizus Rich. Ex D.C. Ph.D Thesis, Universidad Estadual de campinas, Campinas, Brazil.

Sorensen, M., 1996. Yambean Pachyrhizus, DC, Promoting the conservation and use of underutilized and neglected crops 2 . International Plant Genetic Resources Institute, Rome. SPSS 2006. SPSS Inc. 15.0 Evaluation Version for Windows.

Thomas, B., Mashall, A., Hans, B. P. and Barabra, F., 2005. Food safety and security: Fermentation as a tool to improve nutritional values of African yam bean. In: Proceedings of International Agricultural Research for Development. Stuttgart Hohenheim. Tropentag.

Tuleun, C. D., Carew, S. N. and Ajiji, I., 2008a. The feed value of velvet beans (Mucuna utilis) for laying chickens. Proceedings of the $33^{\text {rd }}$ Annual conference of the Nig. Society for Animal Production, Olabisi Onabanjo Univ. Ayetoro. Ogun State March $16-20^{\text {th }}, 2008$. PP. $405-408$.

Tuleun, C. D., Carew, S. N. and Patrick, J. A., 2008b. Proximate and anti-nutritional factors profile of some varieties of velvet beans (Mucuna spp.) found in Benue State of Nigeria. Proceedings of the $13^{\text {th }}$ Annual Conference of the Animal Science Association of Nigeria (ASAN), ABU, Zaria Sept. 15 - 19 2008, Pp. 550 - 553.
Udedibie, A. B. I. and Mba, U. N., 1994. Studies on the use of Pigeon pea (Cajanus cajan) as feed ingredient in layers diet. J. App. Chem. And Agric. Res. 1(1): 1 - 5 .

Udedibie, A. B. I. and Nkwocha, C. O., 1990. Comparative study of Jackbean and Sword bean as protein supplements for young broiler chicks. Agric. J. 24: 7 - 11.

Ukachukwu, S. N., 2000. Chemical and nutritional evaluation of Mucuna cochinchinensis Bean as alternative protein ingredient in broiler diets. Ph.D. Thesis. Department of Animal Science, Faculty of Agriculture, University of Nigeria, Nsukka.

Ukachukwu, S. N. and Obioha, F. C., 2000. Effect of time duration of thermal treatments on the nutritive value of Mucuna Cochinchinensis. Global Journal of Pure and Appl. Sciences, 6(1): $11-15$.

Ukachukwu, S. N., Ezeagu, I. E., Tarawali, G. and Ikeorgu, J. E. G., 2002. Utilization of Mucuna as food and feed in West Africa. Proceedings of an International Workshop. Tegucigalpa. April, 26 29, 2002 Honduras. CIEPCA, and Judson College Honduras, PP. $189-217$.

Ukpabi, U. H., 2007. Evaluation of mucuna seed meal based diets for goat production in South Eastern Nigeria. Ph.D Thesis. Micheal Okpara University of Agriculture, Umudike - Abia State - Nigeria.

Wheeler, V. E. and Ferrel, F. E., 1971. A method of phytic acid determination in wheat fraction. Cereal Chemistry, 48: $312-316$.

Wokoma, E. C. and Aziagba, G. C., 2001. Sensory evaluation of Dawa - Dawa produced by traditional fermentation of African yambean (Sphenostylis stenocarpa Harms) Seeds. J. Applied Sci. and Environ. Mgt. 5(1): 85 - 91. 